\title{
Evaluation and selection of candidates for liver transplantation: an economic perspective
}

\author{
Santiago RODRÍGUEZ ${ }^{1}$, Fabio Da MOTTA2 ${ }^{2}$ Giacomo BALBINOTO NETO ${ }^{3,4}$ and Ajacio BRANDÃ01,5
}

Received: 4 September 2019

Accepted: 30 October 2019

ABSTRACT - Background - Over the next 20 years, the number of patients on the waiting list for liver transplantation (LTx) is expected to increase by $23 \%$, while pre-LTx costs should raise by $83 \%$. Objective - To evaluate direct medical costs of the pre-LTx period from the perspective of a tertiary care center. Methods - The study included 104 adult patients wait-listed for deceased donor LTx between October 2012 and May 2016 whose treatment was fully provided at the study transplant center. Clinical and economic data were obtained from electronic medical records and from a hospital management software. Outcomes of interest and costs of patients on the waiting list were compared through the Kruskal-Wallis test. A generalized linear model with logit link function was used for multivariate analysis. $P$-values $<0.05$ were considered statistically significant. Results - The costs of patients who underwent LTx $(\$ 8,879.83 ; 95 \%$ CI $6,735.24-11,707.27 ; P<0.001)$ or who died while waiting $(\$ 6,464.73 ; 95 \%$ CI $3,845.75-10,867.28 ; P=0.04)$ were higher than those of patients who were excluded from the list for any reason except death $(\$ 4,647.78 ; 95 \%$ CI $2,469.35-8,748.04 ; P=0.254)$ or those who remained on the waiting list at the end of follow-up. Conclusion - Although protocols of inclusion on the waiting list vary among transplant centers, similar approaches exist and common problems should be addressed. The results of this study may help centers with similar socioeconomic realities adjust their transplant policies.

HEADINGS - Health care costs. Waiting lists. Liver transplantation. Health evaluation.

\section{INTRODUCTION}

Liver transplantation (LTx) is the treatment of choice for acute or chronic cases of end-stage liver disease ${ }^{(1-3)}$. In recent years, despite an increased number of LTx procedures performed worldwide ${ }^{(4)}$, organ shortage remains an important challenge for transplant teams. Consequently, time on the waiting list also increases, as well as morbidity and mortality of potential recipients, who sometimes leave the waiting list because of poorer clinical status or death ${ }^{(3,5-7)}$.

The selection of transplant candidates should be as careful as possible for allowing best use of those scarce resources (i.e., allografts); however, the concept of best use may have different interpretations. While the patient is wait-listed, the transplant team must focus on managing the underlying disease and its complications, so that the patient is in proper conditions at the time of $\operatorname{LTx}^{(7-9)}$. Additionally, in this pre-LTx period, costs are relevant and related to disease severity ${ }^{(10-13)}$.

In several countries, including Brazil( ${ }^{(14)}$, deceased donor organ allocation is based on disease severity, i.e., the organ is donated to the wait-listed patient at highest risk of death. The Model for End-stage Liver Disease (MELD) score has been commonly used to estimate disease severity ${ }^{(4)}$. A projection model has predicted that, over the next 20 years in the United States (US), the number of patients on LTx waiting list will increase by $23 \%$, while pre-LTx treatment costs will increase by $83 \%{ }^{(15)}$.

The aim of this study was to evaluate direct medical costs in the pre-LTx period from the perspective of a Brazilian tertiary care center.
METHODS

\section{Cohort selection}

A retrospective cohort, cost-of-illness study was conducted. To be eligible, patients should be aged $>18$ years, male or female, waitlisted for deceased donor LTx from October 2012 to May 2016, and included in the adult LTx group at a tertiary care center in Southern Brazil. Patients on the waiting list because of severe acute liver failure or need of re-LTx were excluded, as well as those under evaluation or on the waiting list for transplantation but regularly treated at other hospitals, where they underwent tests or were admitted, according to clinical progression. Patients were monitored until December 31, 2016 , to potentially complete a follow-up of at least seven months.

\section{MELD score and Brazilian scoring criteria}

In Brazil, organ allocation for deceased donor LTx is based on the MELD score. The minimum score for being wait-listed is $11^{(16)}$. However, the MELD score fails to accurately predict risk of death in some patients, which is why they are assigned extra points and then wait-listed with a minimum score of 20. If LTx is not performed within three months, the assigned score is 24 , increasing to 29 six months after inclusion on the waiting list ${ }^{(16)}$. Since the implementation of this scoring system, the number of points assigned to patients who are eligible to extra points has not changed. The following situations are listed as special and may provide extra points: hepatocellular carcinoma (HCC),

Declared conflict of interest of all authors: none

Disclosure of funding: no funding received. Santiago Rodríguez is a CAPES (Coordenação de Aperfeiçoamento de Pessoal de Nível Superior) scholarship recipient.

${ }^{1}$ Universidade Federal de Ciências da Saúde de Porto Alegre (UFCSPA), Programa de Graduação em Medicina, Porto Alegre, RS, Brasil. ${ }^{2}$ Santa Casa de Misericórdia de Porto Alegre, Porto Alegre, RS, Brasil. ${ }^{3}$ Universidade Federal de Rio Grande do Sul (UFRGS), Programa de Graduação em Economia, Porto Alegre, RS, Brasil. ${ }^{4}$ Instituto de Avaliações de Tecnologias e Saúde (IATS), Porto Alegre, RS, Brasil. ${ }^{5}$ Santa Casa de Misericórdia de Porto Alegre, Grupo de Transplante de Fígado, Porto Alegre, RS, Brasil.

Research performed at: Complexo Hospitalar Irmandade Santa Casa de Misericórdia de Porto Alegre (ISCMPA), Porto Alegre, RS, Brasil.

Corresponding author: Santiago Rodríguez. E-mail: santy_rodri03@yahoo.com 
resectable metastatic neuroendocrine tumor with removed primary tumor and no evidence of extrahepatic metastases, familial amyloid polyneuropathy, hepatopulmonary syndrome, resectable fibrolamellar carcinoma without extrahepatic disease, and metabolic diseases with indication for transplantation. If approved by a Technical Committee, patients with cirrhosis are considered for inclusion with extra points because of: a) refractory ascites or b) recurrent or persistent hepatic encephalopathy ${ }^{(16)}$.

\section{Study variables}

Data were obtained from patients' electronic medical records, including demographic and clinical characteristics, MELD score at inclusion, dates of inclusion, death, exclusion or transplantation, number and type of prescribed medications, number of laboratory and imaging tests, number of visits to medical and non-medical professionals, and number of admissions in the study period.

\section{Economic evaluation}

This cost-of-illness study used the perspective of a transplant center. Only direct medical costs - those directly used for a given procedure or treatment - were analyzed, so that the sum of the incurred costs would represent an objective measure of resource use ${ }^{(17-19)}$.

To allocate all incurred direct medical costs, the hospital accounting department adopts the following methods: a) absorption costing associated with RKW (Reichskuratorium für Wirtschaftlichkeit), or full absorption costing; and b) micro-costing ${ }^{(20,21)}$. In the full absorption costing method, each hospital unit is considered a cost center, i.e., consists of an autonomous production unit with specific coverage areas and incurred costs. Brazilian legislation provides for this method, which is the most widely used in hospitals ${ }^{(22)}$. Each cost center receives funds to pay for overheads, medical and non-medical staff, materials and medications using distribution criteria defined by the hospital. Because LTx is a sequential process, costs of treatments and procedures are allocated to each cost center - micro-costing - based on each patient's flow through different hospital units. The breakdown of all incurred costs in a given cost center, either divided by service unit or by consumption unit in the case of materials and medications, results in unit costs, whose sum corresponds to the total amount of resources used. The information on costs of hospital procedures represents the combination of incurred costs in the functional structure and how they are used in patient care.

\section{Data analysis}

Twenty-nine cost centers were identified. Expenses of materials and medications were analyzed separately. The hospital bill was obtained using a hospital management software (Phillips Tasy ${ }^{\mathbb{}}$; Phillips Clinical Informatics, Blumenau, SC, Brazil). All costs were converted from Brazilian reais (R\$) to US dollars (\$) using the Central Bank of Brazil currency converter (available at: http:/www4.bcb.gov.br/pec/ conversao/conversao.asp. Accessed on April 8, 2018). Because of little variation in quotations in 2017, an exchange rate of $\$ 1=R \$ 3.307$, as of December 31, 2017, was used. To compare economic data from 2012 to 2016, values were standardized using the Brazil Consumer Price Index for the period (available at: http://pt.global-rates.com/ estatisticas-economicas/inflacao/indice-de-precos-ao-consumidor/ ipc/brasil.aspx. Accessed on April 1, 2018) $)^{(17,23)}$.

\section{Cost comparison}

Costs per patient were divided into two periods of care: a) evalua- tion for inclusion on the waiting list and b) staying on the waiting list until outcome of interest (transplantation, death, exclusion due to any reason [except death], or remaining on the list at the end of follow-up). The evaluation period covered from date of registration to 24 hours before date of inclusion, while the waiting period covered from date of inclusion to 24 hours before transplantation or any other outcome of interest.

\section{Statistical analysis}

Quantitative data were described as mean and standard deviation. If the assumptions of normality were violated, median and interquartile range were used. Categorical data were reported as count and percentage. Student's t-test or Mann-Whitney U test was used to compare means in case of skewed distribution. Categorical data were compared using chi-square test or Fisher's exact test. Waiting list costs were compared using a generalized linear model based on generalized estimated equations (GEE) with logit link function (gamma distribution) because data were positively skewed. Four outcomes were included in this model and adjusted for MELD score, age, and refractory ascites. $P$-values $<0.05$ were considered statistically significant. IBM SPSS software package, version 22.0 for Windows (IBM, Armonk, NY, US) was used for statistical analysis.

\section{Ethical standards}

This study follows guidelines for reporting observational studies $^{(24)}$ and was approved by the hospital Research Ethics Committee (protocol no. 1.386. 991). Informed consent was waived because of the non-interventional and retrospective design of the study. All researchers signed a data use agreement to ensure data safety and ethical use.

\section{RESULTS}

\section{Characteristics of the sample}

From October 1, 2012 to May 31, 2016, 172 patients were included on the waiting list for deceased donor LTx. Of those, 30 patients were excluded from analysis because they had acute liver failure or required re-LTx and 38 were excluded because they were regularly treated at other hospitals. Therefore, the final sample consisted of 104 patients, who were divided into four groups: a) 56 patients who underwent LTx (53.85\%); b) 14 patients who died while waiting for LTx $(13.46 \%)$; c) 10 patients who were excluded from the waiting list due to any reason except death $(9.62 \%)$; and d) 24 patients who remained on the waiting list at censorship (23.08\%).

Most wait-listed patients were men (67.3\%), and mean age was $57.26 \pm 8.89$ years. The most common etiology for chronic liver disease was hepatitis $\mathrm{C}$ virus (HCV) (55.8\%), followed by alcohol (12.5\%). Forty-seven patients $(45.2 \%)$ were wait-listed because of HCC. The most frequent comorbidities were hypertension (27.9\%) and type 2 diabetes $(22.1 \%)$. Clinical and demographic data regarding the four groups at inclusion are shown in TABLE 1.

\section{Costs and outcomes of wait-listed patients}

The total pre-LTx cost of 104 patients was $\$ 531,173.60$. Of this amount, $42 \%(\$ 222,175.68)$ of the costs corresponded to the evaluation period and $58 \%(\$ 308,997.92)$ to the waiting period. TABLES 2,3 , and 4 describe the costs of the four groups in both periods categorized by hospital unit. 
TABLE 1. Clinical and demographic data of 104 wait-listed patients stratified according to outcome while waiting for LTx.

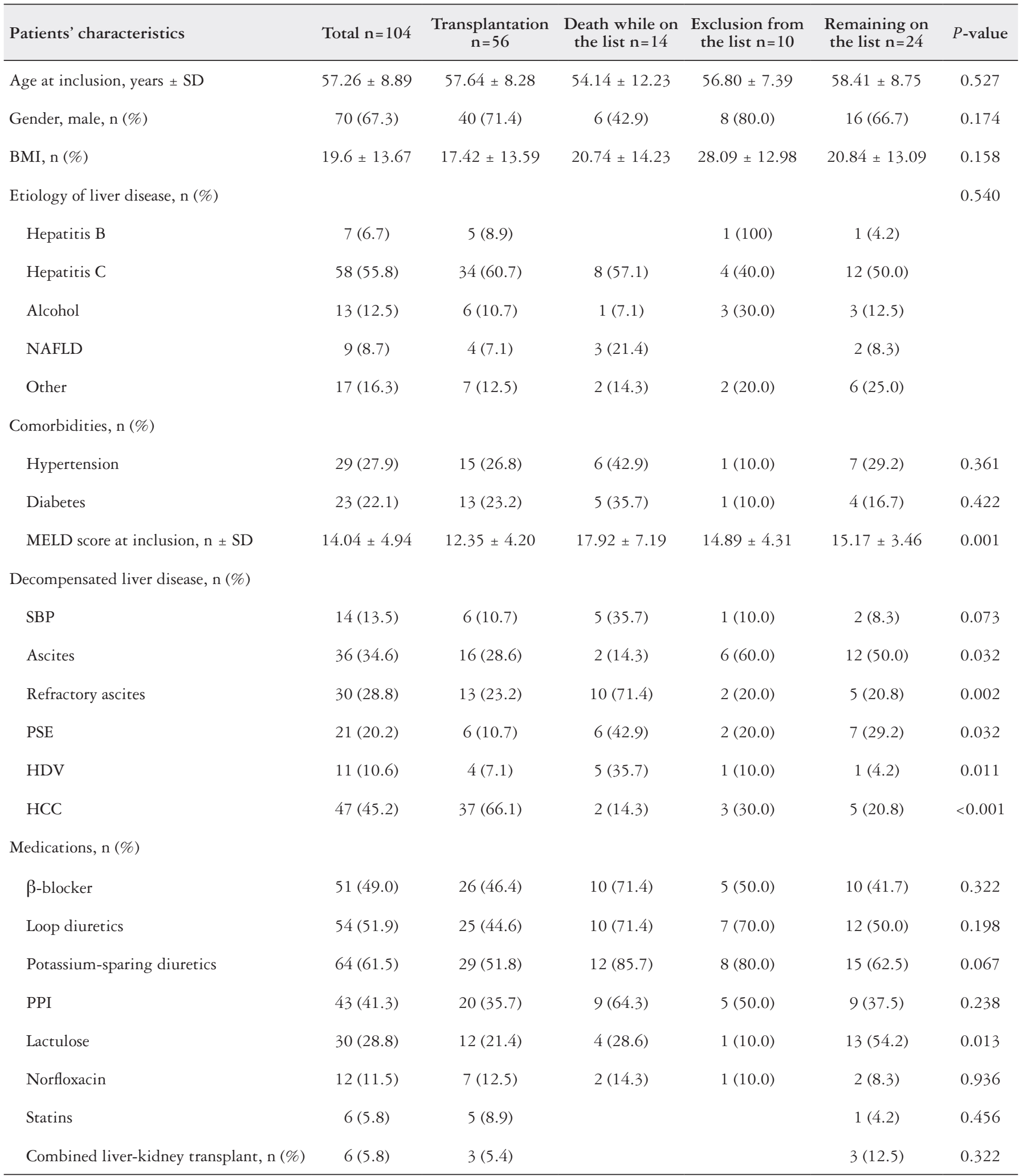

Data expressed as mean \pm SD or median (interquartile range). MELD score: data on 100 patients. BMI: body mass index; HCC: hepatocellular carcinoma; HDV: hepatitis D virus; MELD: Model for End-stage Liver Disease; NAFLD: nonalcoholic fatty liver disease; PPI: proton pump inhibitor; PSE: portosystemic encephalopathy; SBP: spontaneous bacterial peritonitis. 
TABLE 2. Direct medical costs of the evaluation period categorized by cost center and by outcome on the waiting list $(\mathrm{n}=104)$

\begin{tabular}{|c|c|c|c|c|c|c|c|c|c|c|c|c|c|c|c|c|}
\hline \multirow[b]{2}{*}{ Cost Center } & \multicolumn{4}{|c|}{ Transplantation $(\mathrm{n}=56)$} & \multicolumn{4}{|c|}{ Death $(n=14)$} & \multicolumn{4}{|c|}{ Exclusion $(n=10)$} & \multicolumn{4}{|c|}{ Remaining on the list $(n=24)$} \\
\hline & $\mathrm{n}^{* *}$ & $\begin{array}{c}\text { Cost/Unit } \\
(\text { US \$)* }\end{array}$ & $\begin{array}{l}\text { Total } \\
\text { (US \$) }\end{array}$ & $\%$ & $\mathrm{n}^{* *}$ & $\begin{array}{l}\text { Cost/Unit } \\
(\text { US \$)* }\end{array}$ & $\begin{array}{c}\text { Total } \\
\text { (US \$) }\end{array}$ & $\%$ & $\mathrm{n}^{* *}$ & $\begin{array}{c}\text { Cost/Unit } \\
\text { (US \$)* }\end{array}$ & $\begin{array}{c}\text { Total } \\
\text { (US \$) }\end{array}$ & $\%$ & $\mathrm{n}^{* *}$ & $\begin{array}{l}\text { Cost/Unit } \\
(\text { US \$)* }\end{array}$ & $\begin{array}{c}\text { Total } \\
\text { (US \$) }\end{array}$ & $\%$ \\
\hline \multicolumn{17}{|l|}{ Outpatient services } \\
\hline LTx office & 318 & 43.19 & $2,526.56$ & 1.85 & 56 & 43.19 & 759.51 & 2.59 & 40 & 43.19 & 626.24 & 2.68 & 92 & 43.19 & $1,576.39$ & 4.79 \\
\hline Specialties office & 224 & 26.98 & $3,203.00$ & 2.35 & 55 & 64.78 & 734.22 & 2.50 & 28 & 30.72 & 594.4 & 2.54 & 66 & 23.35 & 897.99 & 2.73 \\
\hline Social work & 102 & 7.68 & 38.40 & 0.03 & 24 & 7.68 & 7.68 & 0.03 & 18 & & & & 44 & 7.68 & 53.76 & 0.16 \\
\hline \multicolumn{17}{|l|}{ Inpatient services } \\
\hline Emergency department & 60 & $1,368.75$ & $29,342.54$ & 21.49 & 20 & $1,253.69$ & $10,589.27$ & 36.05 & 3 & 729.53 & 729.53 & 3.12 & 10 & 629.14 & $3,774.79$ & 11.47 \\
\hline Inpatient unit & 120 & 745.15 & $20,627.45$ & 15.11 & 30 & 750.14 & $4,122.82$ & 14.04 & 45 & $1,370.21$ & $8,564.83$ & 36.65 & 3 & 599.73 & 599.73 & 1.82 \\
\hline ICU & & & & & 1 & 778.24 & 778.24 & 2.65 & 3 & $2,520.00$ & $2,520.00$ & 10.78 & & & & 0.00 \\
\hline Surgical unit & 3 & 365.07 & $1,110.85$ & 0.81 & 1 & 178.59 & 178.59 & 0.61 & & & & 0.00 & 1 & 186.46 & 186.46 & 0.57 \\
\hline Physical therapy & 36 & 34.78 & 208.69 & 0.15 & 7 & 32.74 & 32.74 & 0.11 & 32 & 139.13 & 278.25 & 1.19 & 2 & 16.37 & 16.37 & 0.05 \\
\hline Nutrition & 111 & 4.22 & 53.28 & 0.04 & 40 & 0.00 & 0.00 & 0.00 & 26 & 4.22 & 8.44 & 0.04 & 38 & 0.00 & 0.00 & 0.00 \\
\hline Neuroradiology & 8 & $2,120.05$ & $11,432.74$ & 8.37 & 4 & $3,387.69$ & $3,387.69$ & 11.53 & 2 & $1,501.65$ & $3,003.30$ & 12.85 & 2 & $5,892.40$ & $5,892.39$ & 17.91 \\
\hline Chemotherapy & 4 & 15.89 & 197.31 & 0.14 & 2 & 29.73 & 29.73 & 0.10 & 1 & 8.96 & 8.96 & 0.04 & 6 & 791.00 & 790.96 & 2.40 \\
\hline Hemotherapy & 49 & 20.43 & 950.81 & 0.70 & 10 & 20.43 & 281.39 & 0.96 & 8 & 20.43 & 333.02 & 1.42 & 22 & 20.43 & 452.85 & 1.38 \\
\hline \multicolumn{17}{|l|}{ Imaging tests } \\
\hline Computed tomography & 84 & 202.79 & $22,919.39$ & 16.79 & 16 & 133.44 & $1,719.23$ & 5.85 & 6 & 171.49 & $1,144.70$ & 4.90 & 18 & 133.37 & $2,857.48$ & 8.69 \\
\hline MRI & 92 & 270.11 & $18,253.78$ & 13.37 & 7 & 201.10 & $1,977.88$ & 6.73 & 8 & 203.50 & $2,039.91$ & 8.73 & 16 & 201.10 & $4,177.84$ & 12.70 \\
\hline Echocardiography & 35 & 62.22 & $2,587.00$ & 1.89 & 7 & 63.94 & 445.43 & 1.52 & 7 & 62.22 & 502.94 & 2.15 & 16 & 62.22 & $1,067.91$ & 3.25 \\
\hline Ultrasound & 34 & 56.04 & $1,116.14$ & 0.82 & 10 & 63.23 & 439.80 & 1.50 & 8 & 47.48 & 240.27 & 1.03 & 9 & 63.23 & 498.72 & 1.52 \\
\hline Electrocardiogram & 3 & 7.89 & 31.54 & 0.02 & & & & 0.00 & & & & 0.00 & & & & 0.00 \\
\hline Electroencephalogram & 4 & 28.88 & 115.53 & 0.08 & 1 & 28.88 & 28.88 & 0.10 & 4 & 57.76 & 115.53 & 0.49 & 4 & 28.88 & 115.53 & 0.35 \\
\hline Mammography & 1 & 24.34 & 24.34 & 0.02 & 1 & 24.34 & 24.34 & 0.08 & & & & 0.00 & 1 & 48.68 & 48.68 & 0.15 \\
\hline Radiology & 62 & 18.65 & 952.55 & 0.70 & 7 & 18.66 & 149.26 & 0.51 & 5 & 18.65 & 152.83 & 0.65 & 17 & 18.66 & 405.56 & 1.23 \\
\hline Laboratory tests & & & & & & & & & & & & 0.00 & & & & 0.00 \\
\hline Clinical analyses & 312 & 158.03 & $11,158.34$ & 8.17 & 65 & 186.92 & $2,391.69$ & 8.14 & 56 & 166.33 & $1,999.10$ & 8.55 & 92 & 190.27 & $5,524.04$ & 16.79 \\
\hline \multicolumn{17}{|l|}{ Other units } \\
\hline Catheterization laboratory & & & & 0.00 & & & & 0.00 & 2 & 11.02 & 22.05 & 0.09 & 1 & 684.26 & 684.26 & 2.08 \\
\hline Endoscopy & 60 & 240.75 & $8,837.04$ & 6.47 & 12 & 122.06 & $1,085.26$ & 3.69 & 2 & 171.11 & 342.22 & 1.46 & 16 & 306.40 & $2,624.03$ & 7.98 \\
\hline Ergometry & 5 & 43.84 & 263.07 & 0.19 & 1 & 43.84 & 43.84 & 0.15 & & & & 0.00 & 6 & 43.84 & 306.91 & 0.93 \\
\hline Pulmonary function tests & 31 & 18.23 & 583.33 & 0.43 & 9 & 18.23 & 164.06 & 0.56 & 6 & 18.23 & 145.83 & 0.62 & 19 & 18.23 & 346.35 & 1.05 \\
\hline Total & & $5,933.02$ & $136,532.78$ & 100.00 & & $7,451.32$ & $29,371.55$ & 100.00 & & $7,317.42$ & $23,372.35$ & 100.00 & & $5,100.49$ & $16,292.66$ & 100.00 \\
\hline
\end{tabular}

MRI: Magnetic Resonance Imaging; LTx: Liver Transplantation; ICU: Intensive Care Unit; US \$: US dollars (exchange rate on 12/31/2017). *Median cost. **Total number of consultations. 
TABLE 3. Direct medical costs of the waiting period categorized by cost center and by primary outcome $(\mathrm{n}=104)$,

\begin{tabular}{|c|c|c|c|c|c|c|c|c|c|c|c|c|c|c|c|c|}
\hline \multirow[b]{2}{*}{ Cost Center } & \multicolumn{4}{|c|}{ Transplantation $(n=56)$} & \multicolumn{4}{|c|}{ Death $(n=14)$} & \multicolumn{4}{|c|}{ Exclusion $(n=10)$} & \multicolumn{4}{|c|}{ Remaining on the list $(n=24)$} \\
\hline & $\mathrm{n}^{* *}$ & $\begin{array}{c}\text { Cost/Unit } \\
\text { (US \$)* }\end{array}$ & Total (US \$) & $\%$ & $\mathrm{n}^{* *}$ & $\begin{array}{c}\text { Cost/Unit } \\
\text { (US \$)* }\end{array}$ & $\begin{array}{l}\text { Total } \\
\text { (US \$) }\end{array}$ & $\%$ & $\mathrm{n}^{* *}$ & $\begin{array}{c}\text { Cost/Unit } \\
\text { (US \$)* }\end{array}$ & $\begin{array}{c}\text { Total } \\
\text { (US \$) }\end{array}$ & $\%$ & $\mathrm{n}^{* *}$ & $\begin{array}{c}\text { Cost/Unit } \\
\text { (US \$)* }\end{array}$ & $\begin{array}{c}\text { Total } \\
\text { (US \$) }\end{array}$ & $\%$ \\
\hline \multicolumn{17}{|l|}{ Outpatient Services } \\
\hline LTx office & 114 & 45.14 & $2,957.39$ & 1.54 & 27 & 64.78 & 626.24 & 0.78 & 20 & 64.78 & 345.51 & 1.67 & 51 & 43.19 & $1,014.94$ & 6.23 \\
\hline Specialties office & 240 & 75.58 & $2,915.27$ & 1.52 & 36 & 30.72 & 476.53 & 0.60 & 18 & 38.4 & 302.72 & 1.46 & 80 & 30.93 & 741.30 & 4.55 \\
\hline Social work & 24 & 7.68 & 99.84 & 0.05 & 24 & 11.52 & 23.04 & 0.03 & 9 & 7.68 & 7.68 & 0.04 & 13 & 7.68 & 92.16 & 0.57 \\
\hline \multicolumn{17}{|l|}{ Inpatient Services } \\
\hline Emergency department & 80 & 633.86 & $37,679.72$ & 19.60 & 63 & $2,060.66$ & $29,759.59$ & 37.28 & 9 & 272.88 & $1,125.11$ & 5.44 & 6 & 625.61 & $2,206.37$ & 13.54 \\
\hline Inpatient unit & 207 & 688.37 & $47,525.03$ & 24.73 & 52 & $1,897.64$ & $6,768.97$ & 8.48 & 48 & $1,720.58$ & $12,009.90$ & 58.10 & 24 & $1,224.39$ & $2,448.79$ & 15.03 \\
\hline ICU & 15 & $3,827.33$ & $11,999.33$ & 6.24 & 40 & $8,054.18$ & $28,174.30$ & 35.29 & & & & 0.00 & & & & 0.00 \\
\hline Surgical unit & 9 & 181.41 & $2,633.87$ & 1.37 & 3 & 270.41 & 965.57 & 1.21 & 1 & 179.07 & 179.07 & 0.87 & 3 & 272.38 & $1,258.62$ & 7.73 \\
\hline Physical therapy & 70 & 40.92 & 519.67 & 0.27 & 40 & 81.84 & 478.75 & 0.60 & 34 & 202.55 & 347.81 & 1.68 & & & & 0.00 \\
\hline Nutrition & 96 & 8.44 & 547.79 & 0.29 & 18 & 59.45 & 180.39 & 0.23 & 36 & 6.33 & 125.25 & 0.61 & 10 & 15.36 & 122.88 & 0.75 \\
\hline Neuroradiology & 30 & $2,321.00$ & $53,172.60$ & 27.67 & 1 & $2,918.48$ & 2918.48 & 3.66 & 1 & $2,504.70$ & $2,504.70$ & 12.12 & 2 & $1,755.84$ & $1,755.84$ & 10.78 \\
\hline Chemotherapy & 12 & 16.69 & 443.89 & 0.23 & & & & 0.00 & & & & 0.00 & 1 & 13.81 & 13.81 & 0.08 \\
\hline Hemotherapy & 28 & 38.77 & $2,687.90$ & 1.40 & 14 & 109.10 & 843.25 & 1.06 & & & & 0.00 & 2 & 11.82 & 23.63 & 0.15 \\
\hline Dialysis & 14 & 609.35 & $1,218.70$ & 0.63 & 8 & 302.57 & 605.15 & 0.76 & & & & 0.00 & & & & 0.00 \\
\hline \multicolumn{17}{|l|}{ Imaging tests } \\
\hline Computed Tomography & 16 & 133.88 & $2,596.94$ & 1.35 & 12 & 403.90 & $1,633.45$ & 2.05 & 5 & 192.79 & 912.11 & 4.41 & 3 & 182.69 & 650.07 & 3.99 \\
\hline MRI & 24 & 249.31 & $7,238.34$ & 3.77 & 1 & 264.25 & 264.25 & 0.33 & 2 & 315.79 & 315.79 & 1.53 & 8 & 382.28 & $1,595.31$ & 9.79 \\
\hline Echocardiography & 15 & 62.22 & 998.97 & 0.52 & 2 & 93.33 & 186.67 & 0.23 & 1 & 62.22 & 62.22 & 0.30 & 5 & 62.22 & 311.11 & 1.91 \\
\hline Ultrasound & 30 & 31.73 & $1,267.30$ & 0.66 & 21 & 87.22 & 803.13 & 1.01 & 6 & 62.20 & 181.63 & 0.88 & 8 & 47.48 & 411.57 & 2.53 \\
\hline Electrocardiogram & 1 & 15.77 & 15.77 & 0.01 & & & & 0.00 & & & & 0.00 & & & & 0.00 \\
\hline Electroencephalogram & & & & 0.00 & & & & 0.00 & & & & 0.00 & 3 & 28.88 & 86.64 & 0.53 \\
\hline Mammography & 3 & 24.34 & 73.01 & 0.04 & 1 & 24.34 & 24.34 & 0.03 & & & & 0.00 & 1 & 48.68 & 48.68 & 0.30 \\
\hline Radiology & 24 & 27 & 548.78 & 0.29 & 20 & 105.84 & 479.34 & 0.60 & 4 & 27.53 & 55.06 & 0.27 & 2 & 35.28 & 70.57 & 0.43 \\
\hline \multicolumn{17}{|l|}{ Laboratory tests } \\
\hline Clinical analyses & 312 & 109.21 & $9,109.14$ & 4.74 & 143 & 272.10 & $3,454.37$ & 4.33 & 40 & 96.87 & 929.28 & 4.50 & 115 & 78.21 & $3,024.57$ & 18.56 \\
\hline \multicolumn{17}{|l|}{ Other units } \\
\hline Urodynamics & & & & 0.00 & & & & 0.00 & 1 & 14.90 & 14.90 & 0.07 & & & & 0.00 \\
\hline Catheterization Laboratory & & & & 0.00 & & & & 0.00 & & & & 0.00 & & & & 0.00 \\
\hline Densitometry & & 12.28 & 12.28 & 0.01 & & & & 0.00 & & & & 0.00 & & & & 0.00 \\
\hline Endoscopy & 24 & 176.87 & $2,722.26$ & 1.42 & 12 & 116.04 & $1,033.86$ & 1.30 & 3 & 190.42 & 924.20 & 4.47 & 4 & 182.03 & 364.07 & 2.23 \\
\hline Ergometry & & & & 0.00 & & & & 0.00 & & & & 0.00 & 1 & 43.84 & 43.84 & 0.27 \\
\hline Day hospital & 20 & 234.48 & $3,090.15$ & 1.61 & 2 & 132.01 & 132.01 & 0.17 & 1 & 310.87 & 310.87 & 1.50 & 1 & 7.89 & 7.89 & 0.05 \\
\hline Pulmonary function tests & 5 & 18.23 & 127.60 & 0.07 & & & & 0.00 & 1 & 18.23 & 18.23 & 0.09 & & & & 0.00 \\
\hline Total & & 9589.86 & $192,201.54$ & 100.00 & & $17,360.38$ & $79,831.68$ & 100.00 & & $6,288.79$ & $20,672.04$ & 100.00 & & $5,100.49$ & $16,292.66$ & 100.00 \\
\hline
\end{tabular}


TABLE 4. Multivariate model comparing the costs of patients on the waiting list (evaluation and waiting periods) between different outcomes.

\begin{tabular}{lcccccc}
\hline & \multicolumn{4}{c}{ Unadjusted values } & \multicolumn{2}{c}{ Adjusted values } \\
\cline { 2 - 7 } Outcome & $\mathbf{n}$ & Cost (US \$) & $95 \%$ CI & Cost (US \$) $)^{\mathrm{a}}$ & $95 \%$ CI & $\boldsymbol{P}^{\mathrm{b}}$ \\
\hline Remaining on the list (ref.) & 24 & $2,056.88$ & $1,354.62-3,123.20$ & $2,857.49$ & $1,877.26-4,349.56$ & - \\
Exclusion & 10 & $4,475.14$ & $2,343.13-8,547.08$ & $4,647.78$ & $2,469.35-8,748.04$ & 0.254 \\
Death & 14 & $8,262.15$ & $4,781.85-14,275.49$ & $6,464.73$ & $3,845.75-10,867.28$ & 0.049 \\
Transplantation & 56 & $7,576.69$ & $5,764.09-9,959.29$ & $8,879.83$ & $6,735.24-11,707.27$ & $<0.001$ \\
\hline
\end{tabular}

CI: confidence interval; US $\$=$ US dollars (exchange rate on 12/31/2017); $P=$ statistical significance obtained in a generalized linear model using a logit link function (gamma distribution)

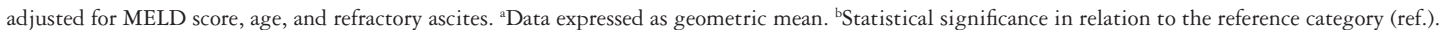

\section{Patients who underwent transplantation}

Fifty-six patients were evaluated, included on the waiting list, fully treated at the hospital, and then transplanted. The cost of these 56 patients in the evaluation period was $\$ 136,532.78$. In this period, the costliest hospital units were Emergency Department $(21.49 \%)$, Computed Tomography (CT) (16.79\%), Inpatient Unit (15.11\%), and Magnetic Resonance Imaging (MRI) (13.37\%). In the waiting period, the total cost was $\$ 192,201.54$. The costliest units were Interventional Radiology (27.67\%), Inpatient Unit (24.73\%), and Intensive Care Unit (ICU) (6.24\%) (TABLES 2 and 3). Materials and medications accounted for $29.85 \%$ and $42.90 \%$ of the total cost in the evaluation and waiting periods, respectively.

HCC was the most common cause of LTx $(61 \%)$, with a statistically significant difference between the groups $(P<0.001)$. Patients with any special criterion (HCC mostly) remained on average 107 days on the waiting list, a significantly shorter time when compared to wait-listed patients without special criterion (136.9 days; $P=0.009$ ).

\section{Patients who died while waiting}

Fourteen patients were evaluated, included on the waiting list, fully treated at the hospital, and died before transplantation. The costs in the evaluation and waiting periods were $\$ 29,371.55$ and $\$ 79,831.68$, respectively (TABLES 2 and 3). In the evaluation period, the costliest hospital units were Emergency Department (36.05\%), Inpatient Unit (14.04\%), Interventional Radiology (11.53\%), and MRI (6.73\%). In the waiting period, the costliest units were Emergency Department (37.28\%), ICU (35.29\%), and Inpatient Unit (8.48\%).

Regarding the severity of liver disease, patients who died had a statistically higher MELD score $(17.92 \pm 7 ; P=0.001)$. Refractory ascites and spontaneous bacterial peritonitis were significantly more frequent in this group (TABLE 1). The most common causes of death were those associated with liver disease $(42.86 \%)$ and infections except for spontaneous bacterial peritonitis $(21.43 \%)$. The mean time between inclusion and death was 124.5 days. Materials and medications accounted for $20.19 \%$ and $24.46 \%$ of costs in the evaluation and waiting periods, respectively.

\section{Patients who were excluded from the list}

Ten patients were evaluated, included on the waiting list, fully treated at the hospital, and excluded before transplantation. The costs of those patients were $\$ 23,372.35$ in the evaluation period and $\$ 20,672.04$ in the waiting period (TABLES 2 and 3). The costliest hospital units in both periods were Inpatient Unit (36.65\% and 58.10\%, respectively) and Interventional Radiology (12.85\% and $12.12 \%$, respectively). The most common causes of exclusion from the waiting list were improved clinical status (30\%) and dropout (30\%). The mean time between inclusion and exclusion was 142 days. Materials and medications accounted for $11.36 \%$ and $19.79 \%$ of total costs in the respective evaluation and waiting periods.

\section{Patients who remained on the list}

TABLES 2 and 3 detail the costs of 24 patients who remained on the waiting list at censorship. The costs in the evaluation and waiting periods were $\$ 32,899.00$ and $\$ 16,292.66$, respectively. The costliest hospital units in the evaluation period were Interventional Radiology (17.91\%), Clinical Analyses (16.79\%), MRI (12.70\%), and Emergency Department (11.47\%). In the waiting period, the costliest units were Clinical Analyses (18.56\%), Inpatient Unit (15.03\%), Emergency Department (13.54\%), and MRI (10.78\%) (TABLES 2 and 3). Materials and medications accounted for $20.88 \%$ and $12.70 \%$ of total costs in the evaluation and waiting periods, respectively.

\section{Multivariate analysis}

In the multivariate model, the outcomes of interest - transplantation, death, exclusion, or remaining on the list - were adjusted for the MELD score at inclusion, age, and refractory ascites (TABLE 4). Patients who underwent transplantation or died while waiting incurred higher costs when compared to patients who remained on the list. Similarly, patients who underwent transplantation were more costly than those excluded from the waiting list $(\$ 8,879.83$ vs $\$ 4,647.78$; $95 \%$ CI 490,39-7973,69; $P=0.027$ ).

\section{DISCUSSION}

Brazil has a consolidated LTx program, ranking third worldwide in absolute number of procedures performed each year, following the US and China ${ }^{(4,14)}$. Organ procurement costs and $95 \%$ of transplants are funded by the Brazilian Unified Health System ${ }^{(14)}$. According to the Brazilian Institute for Applied Economic Research, there was an increase in LTx costs (including medications) between 2004 and 2005 , from $\$ 122.29$ million to $\$ 157.798$ million $^{(25)}$. Thus, because transplant costs are publicly funded, a cost analysis of all LTx phases is even more relevant, in order to ensure a rational use of the limited resources available.

Brazilian economic studies of LTx have addressed costs incurred performing the transplantation itself ${ }^{(26-28)}$. However, for economic evaluations to reflect the actual impact of the procedure on the budget of transplant centers and be used as tools for decision-making, they should include an assessment of potential recipients, inclusion and follow-up of patients on the waiting list (outpatient and inpatient services), as well as post-LTx follow-up ${ }^{(11)}$.

This study evaluated the specific costs to include adult patients on 
the waiting list and to treat them while waiting for LTx, considering the following outcomes of interest: transplantation, death while waiting, exclusion from the list for any reason (except death), and remaining on the list at the end of follow-up. The highest costs (inclusion + follow-up) referred to transplanted patients $(53.8 \%$ of the sample) or patients who died while waiting for LTx (13.5\%).

At inclusion, most transplanted patients had an original MELD score significantly lower than that of the remaining patients, but most of them (66.1\%) had HCC and, therefore, were listed as "special case". The diagnosis of HCC explains why Interventional Radiology had highest expenses (approximately $28 \%$ of total costs), as the unit provides locoregional therapies while patients wait for LTx. Other costly units were Inpatient Unit and Emergency Department.

Approximately $13 \%$ of patients died while waiting for LTx, on average 124 days after being included on the waiting list. These patients had higher MELD scores and $71 \%$ had refractory ascites. In this group, highest costs were observed in the Emergency Department and ICU, i.e., in therapies that sought to keep the patient alive and in proper conditions to undergo LTx. The costs of this group of patients until death was approximately twice that of transplanted patients $(\$ 15,522.88$ vs $\$ 24,811.70)$. Thus, not performing a transplant is also costly, and the resources used in the treatment of patients who die while waiting for transplantation could be considered "hidden" costs of organ shortage for $\mathrm{LTX}^{(10)}$. Patients with more severe conditions (as shown by a higher MELD score) are known to demand more costs ${ }^{(12,13)}$.

Approximately $10 \%$ of patients were excluded from the waiting list. The most common causes were improved clinical status $(30 \%)$ and dropout (30\%). Therefore, a considerable number of patients, when properly treated, may maintain a stable clinical status or even show improvement enough to be excluded from the list. Inpatient Units accounted for the highest costs. Finally, patients who remained on the list at the end of data collection incurred highest costs in the Emergency Department and ICU.

In this study, expense segmentation into cost centers showed that medications, imaging studies, clinical analyses, and length of hospital stay are directly related to higher costs, as demonstrated by a previous Brazilian study ${ }^{(13)}$.
One of the limitations of this study is its retrospective design. In addition, although it was conducted at an excellence center in Brazil, it still is a single-center study. Nonetheless, analyzing costs of inclusion on the waiting list and then dividing costs into usual outcomes of waitlisted patients (transplantation, death, exclusion, and remaining on the list) allowed identifying the costs of different groups of wait-listed patients and the impact from the perspective of the transplant center.

\section{CONCLUSION}

The processes of evaluation for inclusion on the waiting list and waiting for LTx are complex and expensive. Although protocols for evaluation and inclusion of potential recipients depend exclusively on each transplant center, there are common problems that should be analyzed for decision-making: a) disparity between number of waitlisted patients and number of organs available; b) competition involving other transplant centers in the same area not only for candidates but also for organs; and c) particular epidemiological behavior of chronic liver disease in each area ${ }^{(29)}$. These results may help centers from similar socioeconomic realities adjust their policies in order to improve resource use and provide greater benefit for LTx patients both in Brazil and worldwide.

\section{Authors' contribution}

Rodríguez S, Balbinotto GN, and Brandão $\mathrm{ABM}$ were responsible for conception and design of the study, analysis and interpretation of the data, and had overall responsibility. Rodríguez S contributed to data collection and manuscript writing. Motta FL contributed to acquisition and analysis of the data. All authors critically revised the manuscript, agree to be fully accountable for ensuring the integrity and accuracy of the work, and read and approved the final manuscript.

\section{Orcid}

Santiago Rodríguez: 0000-0001-8610-3622.

Fabio Da Motta: 0000-0001-9544-4699.

Giacomo Balbinoto Neto: 0000-0001-8289-1932.

Ajacio Brandão: 0000-0001-8411-5654.

Rodríguez S, Motta F, Balbinoto Neto G, Brandão A. Avaliação e seleção de candidatos para transplante hepático: uma perspectiva econômica. Arq Gastroenterol. 2020;57(1):31-8.

RESUMO - Contexto - Nos próximos 20 anos, estima-se um aumento de $23 \%$ no número de pacientes em lista de espera para transplante de fígado (TxF) e de $83 \%$ nos custos no período pré-TxF. Objetivo - Avaliar os custos médicos diretos do período pré-TxF sob a perspectiva de um centro de atenção terciária. Métodos - Foram incluídos no estudo 104 adultos em lista de espera para TxF, com doador falecido, entre outubro de 2012 e maio de 2016 , tratados integralmente no centro transplantador do estudo. Dados clínicos e econômicos foram obtidos do prontuário eletrônico e do software de gestão hospitalar. Os desfechos de interesse e os custos dos pacientes em lista de espera foram comparados através do teste de Kruskal-Wallis. Um modelo linear generalizado com função de ligação logarítmica foi utilizado para a análise multivariável. Valores de $P<0.05$ foram considerados estatisticamente significativos. Resultados - Os custos com pacientes submetidos a TxF (US\$ 8.879,83; IC 95\% 6.735,24-11.707,27; $P<0,001$ ) ou que morreram enquanto estavam em lista (US\$ 6.464,73; IC 95\% 3.845,75-10.867,28; $P=0,04$ ) foram maiores do que com pacientes excluídos da lista por qualquer motivo, exceto óbito (US\$ 4.647,78; IC 95\% 2.469,35-8.748, $04 ; P=0,254$ ) ou daqueles que permaneceram em lista de espera ao final do seguimento. Conclusão - Embora os protocolos de inclusão em lista de espera variem entre os centros transplantadores, existem condutas semelhantes e problemas comuns devem ser considerados. Os resultados deste estudo podem auxiliar os centros com realidades socioeconômicas semelhantes na adequação das suas políticas de transplante.

DESCRITORES - Custos de cuidados de saúde. Listas de espera. Transplante de fígado. Avaliação em saúde. 


\section{REFERENCES}

1. Russo FP, Ferrarese A, Zanetto A. Recent advances in understanding and managing liver transplantation. F1000Res. 2016;5(F1000 Faculty Rev):2895.

2. Halliday N, Westbrook RH. Liver transplantation: need, indications, patient selection and pre-transplant care. Br J Hosp Med (Lond). 2017;78:252-9.

3. Jackson KR, Cameron A. Liver transplantation: candidate selection and organ allocation in the United States. Int Anesthesiol Clin. 2017;55:5-17.

4. Trotter JF. Liver transplantation around the world. Curr Opin Organ Transplant. 2017;22:123-7.

5. European Association for the Study of the Liver. EASL Clinical Practice Guidelines: liver transplantation. J Hepatol. 2016;64:433-85.

6. Martin P, DiMartini A, Feng S, Brown Jr R, Fallon M. Evaluation for liver transplantation in adults: 2013 practice guideline by the American Association for the Study of Liver Diseases and the American Society of Transplantation. Hepatology. 2014;59:1144-65.

7. Lucidi V, Gustot T, Moreno C, Donckier V. Liver transplantation in the context of organ shortage: toward extension and restriction of indications considering recent clinical data and ethical framework. Curr Opin Crit Care. 2015;21:163-70.

8. O'Leary JG, Lepe R, Davis GL. Indications for liver transplantation. Gastroenterology. 2008;134:1764-76.

9. Nusrat S, Khan MS, Fazili J, Madhoun MF. Cirrhosis and its complications: evidence based treatment. World J Gastroenterol. 2014;20:5442-60.

10. Brand DA, Viola D, Rampersaud P, Patrick PA, Rosenthal WS, Wolf DC. Waiting for a liver--hidden costs of the organ shortage. Liver Transpl. 2004;10:1001-10.

11. Buchanan P, Dzebisashvili N, Lentine KL, Axelrod DA, Schnitzler MA, Salvalaggio PR. Liver transplantation cost in the model for end-stage liver disease era: looking beyond the transplant admission. Liver Transpl. 2009;15:1270-7.

12. Axelrod DA, Dzebisashvili N, Lentine K, Segev DL, Dickson R, Tuttle-Newhall E, et al. Assessing variation in the costs of care among patients awaiting liver transplantation. Am J Transplant. 2014;14:70-8.

13. Turri JAO, Decimoni TC, Ferreira LA, Diniz MA, Haddad LBP, Campolina AG. Higher MELD score increases the overall cost on the waiting list for liver transplantation: a micro-costing analysis based study. Arq Gastroenterol. 2017;54:238-45.

14. Bittencourt PL, Farias AQ, Couto CA. Liver Transplantation in Brazil. Liver Transpl. 2016;22:1254-8

15. Habka D, Mann D, Landes R, Soto-Gutierrez A. Future economics of liver transplantation: a 20 -year cost modeling forecast and the prospect of bioengineering autologous liver grafts. PLoS One. 2015;10:e131764.
16. Brasil. Ministério da Saúde. Portaria 2.600, de 21 de outubro de 2009. Aprova o Regulamento Técnico do Sistema Nacional de Transplantes [Internet]. [cited 2019 April 29]. Available from: http://bvsms.saude.gov.br/bvs/saudelegis/gm/2009/ prt2600_21_10_2009.html.

17. Rascati KL. Medindo e estimando custos. In: Rascati KL. Introdução à farmacoeconomia. Porto Alegre: Artmed; 2010.

18. Ching HY. Fundamentos de custos e métodos de custos. In: Ching HY. Manual de custos de instituições de saúde. Rio de Janeiro: Atlas; 2001.

19. Álvarez JS. Evaluación económica de medicamentos y tecnologías sanitarias Madrid: Springer; 2012.

20. de Matos AJ. Sistemas de custeio aplicados à gestão de custos hospitalares. In: de Matos AJ. Gestão de custos hospitalares: técnicas, análise e tomada de decisão. São Paulo: STS; 2002.

21. Gold MR, Siegel JE, Russell LB, Weinstein MC. Cost-effectiveness in Health and Medicine. New York: Oxford University Press; 1996.

22. Brasil. Ministério da Saúde. Introdução à gestão de custos em saúde. Brasília: Ministério da Saúde; 2013.

23. Drummond M, Sculpher MJ, Torrance GW, O Brien BJ, Stoddar GL. Methods for the economic evaluation of health care programs. Oxford University: Oxford; 2005.

24. von Elm E, Altman DG, Egger M, Pocock SJ, Gøtzsche PC, Vandenbroucke JP, et al. The strengthening the reporting of observational studies in epidemiology (STROBE) statement: guidelines for reporting observational studies. J Clin Epidemiol. 2008;61:344-9.

25. Marinho A. Estado de uma nação: textos de apoio a situação dos transplantes de órgãos no Brasil. Texto para discussão n 1389. Brasília: IPEA; 2009.

26. Coelho JCU, Wiederkehr JC, Lacerda MA, Campos ACL, Zeni Neto C, Matias JEF, et al. Custo do transplante hepático no Hospital de Clínicas da Universidade Federal do Paraná. Rev Assoc Med Bras. 1997;43:53-7.

27. Ferraz AAB, Lopes EPA, Sette MJA, Godoy MMG, Lima MHOLAL, de Araújo Júnior JGC, et al. Custo do transplante hepático no Hospital das Clínicas da Universidade Federal de Pernambuco. Rev Bras Saude Mater Infant. 2002;2: 313-8.

28. Portela MP, Neri EDR, Fonteles MMF, Garcia JHP, Fernandes MEP. O custo do transplante hepático em um hospital universitário do Brasil. Rev Assoc Med Bras. 2010;56:322-6.

29. Saidi RF, Razavi M, Cosimi AB, Ko DS. Competition in liver transplantation: helpful or harmful? Liver Transpl. 2015;21:145-50. 